\title{
Reyog Bulkiyo as a Cultural Potential in The Natural Laboratory of Sounthern Slopes Of Kelud Volcano And its Use For Social Studies Learning Based on Environment
}

\author{
Siti Malikhah Towaf, Sukamto \\ Department of Social Studies, Faculty of Social Sciences \\ State University of Malang, \\ Malang, Indonesia \\ siti.malikhah.fis@um.ac.id
}

\begin{abstract}
Implementing integrated-contextual teaching and learning based on constructivistic theory is needed in Social Studies Education. This study describes the importance of the Natural laboratory and its cultural potentials such as Reyog Bulkiyo and how to use it in promoting an integrated contextual teaching and learning of Social Studies Education in Junior High School. A qualitative approach was used in this study. The researchers carried out documentary studies, observations, interviews, open-ended questions, and focus group discussions. The data were analyzed inductively and comparatively. The results show that the Natural Laboratory of the Faculty of Social Sciences as a new laboratory has a strategic role in promoting the contextual and integrated teaching and learning of Social Study Education. Many cultural and artistic potentials exist in the Natural Laboratory in the forms of cultural activities of the villagers; such as Bersih Desa, Kleningan, Baritan, Celengcelengan, Jaranan and Reyog Bulkiyo etc. The artistic and cultural potentials are needed as materials in Social Studies Education to broaden teachers and students perspectives about the natural environment and the diversity of Indonesian Cultures.
\end{abstract}

Keywords - Reyog, Art, cultural potentials, natural laboratory, contextual, intergrated, Social Studies Education

\section{INTRODUCTION}

Indonesia volcanic zone lanes sweep through along Sumatera, Java, Bali, Nusa Tenggara, Sulawesi, Banda, and Molucca to Papua. It caused Indonesia become very vulnerable to disaster due to material from volcanic eruptions such as lava, volcanic ash and air pollution containing hazardous substances [1]. Kelud is one of the volcanoes, included in the area of Kediri Regency, Malang Regency, and Blitar Regency. Most southern slopes of Kelud include the administrative area of Blitar Regency, always get hit by Kelud' lava which exploded periodically from ancient times until now. This makes the people of Blitar, especially the southern slopes of Kelud familiar and ready to face the eruption [2]. The southern slopes of Kelud consists of forest, plantation and agricultural areas with fertile soil. In addition to the southern slopes of Kelud there are also many sources of water, therefore it is suitable for agriculture, fishery and livestock [3]. The majority of population of the southern slopes of Kelud is Javanese people who work as farmers. Although the southern slope of Kelud is an area prone to disasters of both Kelud eruption and cold lava; but based on the spreading map of the population of Blitar Regency, the southern slope of Kelud inhabited by many peoples [4]. This is because people prefer to live close to the agricultural land which facilitate their activities.

Kelud is one of the active volcano found in East Java Province. This volcano has recorded eruption as much as 33 times since $1000 \mathrm{BC}$ to 2017 [5]. Kelud was last erupted on February 2014; resulted in prolonged trauma and material loss for residents around the slopes of Kelud. Not only the residents of the slopes of Kelud who felt the impact of eruption, but the impact spreader out to West Java Province. In fact, the eruption is called as the biggest eruption in the history of Kelud; but different situation happen in Blitar District, Garum District which are located on the southern slope of Kelud. It is interesting to note that the Kelud eruption in 2014 had little impact on the activities of the population at risk, because the dust of Kelud volcanoes fled far away covering the west part of East Java, Middle and West Java [6]. The agricultural activities of the residents are not much disturbed after the eruption, as well as the economic activities; such as trade, small industry, animal husbandry, fisheries.

After the Kelud disaster the community immediately worked hard for a better life; three years passed by and villagers have been cleaned up their villages until look neat, the houses have been reconstructed with better conditions. As it is seen in the village of Kemloko Nglegok, village Putukrejo, Gadungan and Gandusari District; since early days of life, rolling the various economic bustle can be seen. The fresh milk jugs lined up the sidewalk unattended, a moments later the milk-collecting car passed by and all the milk on the roadside was transported to the collecting place. It is seen also a teenager who was busy bathing four healthy dairy cows as his activities every day. On the streets reaseacher always encounter people who go to the fields, rice fields or coffee plantations; the Head of Dusun Putukrejo said that there is no 
unemployment in his Dusun/small village (Social Studies Program, Field Study, 2017). The welfare of the people, become a fertile ground for the development of various artistic and cultural activities. In this case Abraham Maslow's theories can be be stated; that when the basic human needs or basic physical needs of clothing, food and boards are fulfilled; human activity will lead to higher levels of needs such as for security, comfort, social needs, self-esteem and selfactualization [7], [8].

Social Studies Education is one of the subjects at the Junior High School level having integrated materials refers to the combination of geography, history, sociology and economy. As quoted by [9] that Social Studies Education for the school level is closely related to the social sciences, integrated with the humanities are packed scientifically and pedagogically for the benefit of learning in school. The climate, geology, flora and fauna and inter-space interaction in Indonesia and its influence on human life in economic, social, cultural and educational aspects specifically designed in Social Studies learning. Sociocultural aspects contained in Basic Competency of 3.1 of the Curriculum 2013, the Revised Edition of the year 2016; Social Studies for Junior High School described as understanding the concept of space (location, distribution, potential, climate) as the results of its description into material of Ethnic and Cultural Diversity; not only broadens the perspective of the students, but also includes strengthening character of pride to culture of the nation and love to the country [10], [11]. The Understanding of ethnic and cultural diversity of the community strengthening the identity of students as the nation of Indonesia; it will lead to an understanding of local wisdom that has been existed for a long time in the Region. Thus the object of ethnic and cultural diversities is an appropriate environment around student.

This study took place in Kemloko, Nglegok and Gandusari District, of Blitar Reagency. So the Social Studies material that has been described previously become Ethnic and Cultural Diversity of Nglegok and Gandusari, Blitar District. Based on the observations of researchers there are many potentials of ethnic and cultural diversity in the community of Gandusari District such as Bersih Desa/Cleaning the village tradition, kleningan, baritan/selamatan, mitos of the Rambut Monte Lake, and so forth. Alfath and Permana [12] recognized the Festival of 1000 tumpeng as commodification of Tradition, Tourism and territoriality in Kelud. The diversity is preserved until now and for the following generations. The form of preservation is manifested in the form of festival or carnival which has an impact on the development of tourism potential in Kemloko and Gandusari District. The ethnic and cultural phenomena in the community of Kemloko and Gandusari subdistrict need to be transformed into Social Studies learning materials. The transformation aims to create a contextual Social Studies learning [10], [13].

In addition, the aim of introducing cultural heritages to students is also preserving the culture of the community in Kemloko and Gandusari District [12]. The form of transformation can be through the development of Social Studies learning media which contain various forms of art and cultures that exist in the community. The development and utilization of well-designed and creative instructional media in
Social Studies learning can strengthen students' understanding in order to achieve the defined competencies. A learning media can also help students improve understanding, facilitate interpretation of data and condense information. The presence of learning media in the learning process of Social Studies has a significant impact, because the vagueness of messages or information conveyed by teachers can be helped by presenting the medium of learning. Social Studies teachers less optimal in using learning media in the teaching process of Social Studies. It was stated that the availability of Curriculum 2013 materials in the form of a book package is still not sufficient and every theme taught has not been made in the form of learning media because the lesson is still based on the package book given by the central government [14]. Social Studies teachers more often ask students to read the book package and work on student worksheets, this the common instructional process

In this case, Reyog Bulkiyo is a phenomenal cultural form in the Kemloko District, Muntadhirotul [15] interested in analyzing the choreography of Reyog Bulkiyo. As a dancing form Reyong Bulkiyo choreography representing the fighting spirit of Diponegoro troops; it is not only performed many skills of military personnel but also the way of the troops having fun with his friends in difficult situation. Another researcher [16] focus his study on the existence of Reyog Bulkiyo in Blitar Regency. He showed that there are two factors have an impact on the existence of Reyog Bulkiyo. First, the internal factors come from the art itself; the actors of Reyog Bulkiyo have a very strong fighting spirited in performing the art. They maintain the preserving spirit by educating their descendant from generation to the next. The external factors are related to the community who support the performance of Reyog Bulkiyo; included the local government and related institution, and the society at large who enjoy the performance, researcher also interested in studying Reyog Bulkiyo as a performance art. It is said that in the year of 1980 was the golden decade of Reyog Bulkiyo performance. The group was frequently invited by Blitar Government/The Art Council of Blitar Regency) in many art festivals [16].

The aim of this study is to describe: 1) Social Studies learning objectives and strategies, 2) The importance of natural laboratory for Social Studies Learning, 3) The potential of socio-cultural on the southern slopes of Kelud as the Natural Laboratory of Social Studies, 4) How is Reyog Bulkiyo can be used as the theme of Social Studies integrated material. With the use of various socio-cultural potentials from the surrounding environment, a constructive contextual learning will be more easily developed [13]. Teachers will be more enthusiastic if the learning material and media based on the potentials of the Natural Laboratory on the slopes of Kelud available for them; they can enrich the learning of Social Studies and make students learn effectively and happily.

\section{RESEARCH METHODS}

This research used a qualitative approach with descriptive type. In qualitative research, objects are examined in conditions in natural state/natural setting [17], [18]. Researchers do not change the condition of the object to dig information and focuses on human action and experience. This research was conducted with descriptive type, as a study intended to 
investigate the circumstances, conditions, situations, and events [19]. Researchers do not stop at descriptive explanations alone, but also understand the reasons and causes of action to seek interrelationship between findings. As a key instrument, researcher become collector of data in this study to explore what they are thinking and experiencing. The data collection in this study lasted for 5 months, it was started from March to July 2017. This research was conducted in several villages on the southern slopes of Kelud Mountain such as Putukrejo, Gadungan, and Kemloko area, in Blitar Regency. The facts and words were presented in the way they were and then examined [20]. As a key instrument the role of researchers is quite complex; it needs to be diligence and precautions in the process of data collection.

The type of data in this study is divided into two kinds: primary data and secondary data. Source that directly provide data to the data collector. The primary data in this study were obtained from the primary source obtained through observation and interview. Secondary data obtained from sources that do not directly provide data to data collectors. This type of data is obtained from literature materials in the form of documents, books, and journals related to research problems [21]. The secondary data include the Kelud mountain profile, village of Putukrejo, Gadungan, and Kemloko in Blitar Regency as well as articles supporting research. The data analysis was performed in interactive patterns, comparing, categorizing and drawing conclusions [20], [22]. The validity of the data is obtained through observation, triangulation, and peer discussions. The researcher gave an accurate and systematic description of what was observed by increasing observational persistence [18].

\section{THE DESCRIPTION OF DATA AND DISCUSSION}

\section{A. The Need to the Natural Laboratory}

The Social Studies Education is definitively described as a subject that: 1) The goals derive from citizenship in a democratic society in relation to other nations of the world; 2) The contents are drawn mainly from history, social sciences and some from humanities and sciences; 3) Taught in a way that reflects the growing awareness of personal, social, cultural experience, and according to the level of student development. The main purpose of Social Studies Education is to help students learn about the social world in which they live, face social reality, develop knowledge, attitudes, values, and skills including: social skills, study skills, work habits, group work skills and intellectual skills needed to enlighten humanity [9], [23]. This definition become the main source in describing the goals and the learning strategy of Social Studies Education.

Previous studies showed that the learning practice of Social Studies undergoes a lot of unappropriated process; the Social Studies learning developed by the teachers only concerns the aspects of low-level cognitive domain, and the learning process is more adhered to simple models based on behavioristic learning theory [24]. Not surprisingly, if the evaluation model of the Social Studies learning outcomes is dominated by multiple-choice objective test that in favor to memorizing and understanding skills with little application of conceptualization capability. The result is certainly predictable that Social Studies
Education is no more than a subject to memorize social knowledge information, less meaningful for students' social life. In learning, schools are required to make changes about what students have to learn and how students learn, so that students have skills that fit the demands of the $21^{\text {st }}$ century [11]. Social Studies subject can play an important role, not just cognitively and affectively; but also for the development of social skills of learners such as interpersonal skills, crossnetwork collaboration skills, social and cross-cultural interaction skills, personal and social responsibilities, interactive communication, cultural literacy and global awareness it is strengthening characters of the learners [25].

Integrated learning as a process of organizing material in social Studies has several characteristics, namely: student centered, the learning process prioritizes the provision of direct experience, and the separation between students' eyes is not apparent. Besides, integrated learning presents the concept of various subjects in one learning process. The benefits of integrated learning are, many of the topics contained in each subject have conceptual relevance learned by the learners [26], [27]. As a consequence of each lesson, a particular theme will be conveyed by an Social Studies teacher and in discussion should be analyzed from four aspects, namely geography, history, economics, and sociology. The arrangement of themes can be based on social problems that exist in society or the potential/superiority of a region that analyzed from various disciplines or perspectives of Social Sciences.

In order to carry out an integrated learning, several requirements are needed include: carefulness of teachers in anticipating the use of various hints of conceptual intra or inter subjects; mastery of materials and methodology to the subjects that can be linked. Fadillah [28] argued that the meaning of integrative thematic learning is that in the learning is made per theme with reference to the characteristics of learners and implemented in an integrated way between themes with one theme and between subjects one with the eyes another lesson. There are several things teachers need to prepare before implementing thematic-integrative learning [27], [28]. Teachers should: 1) carefully examine and digest competency standards, basic competencies and indicators to be achieved in learning a topic. 2) Sitting together with other subject teachers to discuss the integration of topics as closely as possible. There are several subjects which are necessary for teacher discussion: a) coverage of learning indicators, b) the scope of topics and sub-topics, c) maximizing the relevance of the topic with the learner's life; d) assigning tasks/projects that integrate subjects as closely as possible. The task/project can be a simple problem solving around the learner's life according to the topic. 3) Creatively preparing materials and instructional media in accordance with the level of ability and interest of students. 4) Open attitude, it is not the time of entry into force of opinion that teacher knows everything. In the present teacher should be open to receive input and criticism from learners, teacher capacity is as a companion. 5) Flexible in the implementation of learning refers to the achievement of learning objectives.

In the implementation of KTSP may include exploration process (exploration or exploration to look for something whose existence is not yet known), elaboration (extension or merging typical activities at a higher level of thought), and 
confirmation (reinforcement of something right) [29]. Then the 2013 curriculum recommends the use of Scientific Approach in the learning process consists of the following 7 steps: 1) observe, 2) ask question, 3) try, 4) process, 5) present, 6) conclude, and 7) create. These suggestions can be addressed as alternatives can be chosen by the teacher as needed; because basically science Instructional Design abbreviated ID or learning design is the science of It Depend (depending on the needs) of various aspects of the learning itself.

The existence of laboratories in an educational institution is not only a monopoly in the field of science but more according to need. In the Faculty of Literature there has long been language laboratories, computers and the Arts. Called the laboratory as a means of supporting the implementation of education by the Study Program/Lecturer and learning in the classroom by student's teacher. At the Faculty of Social Sciences, various departments have their own laboratories. The Social Studies Education Program is a new Program accept students since 3 years ago realize the need to Social Studies Education Laboratory. The Laboratory which is located in the Faculty of Social Science Building (I1) stand as a supporting facility unit for the Study Program. It is a Laboratory with an organizational structure: Chairman of Laboratory, Laboratory, Administrative Staff, Technician and Chairman of Division/part as needed. As a Study Program under Higher Education then the Division in Laboratory will be compatible with Tri Dharma Perguruan Tinggi (Three services of Higher Education) consisting of Education and Teaching division, Research and Community Service Divisions; each division will develop its own program according to the needs of the Social Studies Education.

The first division is Education and Teaching, will collects: Document Curriculum of Primary and Secondary Education ever, especially those being used such as Curriculum 2013 in the field of Social Studies; Social Studies textbooks that have existed and are in use, and books published by various publishers. Various ready-to-use instructional media, as well as development results by Social Studies students as part of lecture duties. Various sources can be used by students in the implementation of teaching practice and many fields study; software and hardware required for learning activities, etc [30]. The second, is a Research division will be responsible to create a research planning program, collecting research reports in the field; literature/books on research methods required in Social Studies Research. Holding collegial discussions as well as with students to find titles developed by lecturers and students to create research proposals; Utilization of research results for the development of Social Studies program; etc. The third is Devotion to the Community, developing program of devotion by and for students, collecting reports of community activities by and within the field of Social Studies Education; collect reference books useful for community service activities in the field of Social Studies Education; utilizing the results of community service for Social Studies Education, holding collegial discussions as well as with students to develop activities of devotion related to the field of Social Studies Education.

Constructivist-contextual learning theory becomes the foundation in designing integrated Social Studies learning relevant with K2013 recommendation. In constructive learning strategies, learning is designed to give students the opportunity to construct their own knowledge, by implementing contextual learning/relevant to the settings or material contexts discussed, and manifesting what is called meaningful learning. For that reason K2013 recommends learning models of Problem Based Learning/PBL model, Project Based Learning/PjBL, Discovery or Inquiry learning followed by Decision making model [9] a thematic learning as the implementation of integrated learning. In this strategy, the Natural Laboratory can be used as the learning environment for student-teachers of Social Studies Program and students at schools to construct knowledge and create meaningful learning experiences through an integrated learning process. The essence of integrated learning is started from a particular theme as a center to understand the symptoms, and concepts, both intra-subject and inter-subjects. With the integration, learners will gain deeper knowledge and skills so that learning becomes meaningful for the learners. The meaning of integrated learning is a learning approach that involves several subjects or perspectives to provide meaningful experiences to learners.

\section{B. The Socio-Cultural Potentials of the Natural Laboratory for Social Studies}

The laboratory is not only a room with a variety of equipment in the Faculty of Social Sciences Building; but can also be a Natural Laboratory. The southern slopes area of Kelud with its various potentials and cultural diversity is adopted as the Natural Laboratory for all Study Programs and Departments at the Faculty of Social Sciences. In 2015, the first experience of the Social Studies Education Program manage the Field Work \& Lecture for students. The contextualintegrated learning started from a contextual theme which occurs in the community will be more alive. A natural laboratory-based learning will eliminate the impression embedded in Social Studies Education as a rote-learning subject [26], [27]. An integrated learning is developed to achieve the learning objectives that have been set, students are expected to improve their understanding of the concept learned more meaningfully [30]. Along with the development of the learning field, Social Studies subject can contribute in optimizing the achievement of learning objectives. The application of various models of constructivist learning is necessary to promote effective, efficient and fun learning. Therefore the existence and the availability of the Natural Laboratory becomes a real need for Social Studies learning.

The Curriculum of 2013 mentioned that Social Studies Education examines a set of events, facts, concepts, and generalizations related to social issues. The purpose is to direct learners to become democratic and responsible Indonesian citizens, as well as citizens of a peace-loving world. Without historical understanding there can be no wisdom, without economic understanding there can be no healthy use of resources, no rational approach to decision making and therefore no future, without citizenship understanding there can be no democratic citizen and therefore no democracy [23], [31]. Therefore it needs to be developed in an integrated manner in order to help students understand social aspects holistically, from a historical, sociological, geographical, and 
economic perspective. The Citizenship aspect of Social Studies education was explained bay researcher that in American context Citizenship Education is part of Social Studies Education; while in Indonesia, Citizenship Education course self-developed subject called PpKn (Pancasila and Citizenship Education).

There are many potentials for ethnic and cultural diversity in the community on the slopes of Kelud, especially in Kemloko and Gandusari District, such as tradisi bersih desa (the Village cleaning event) which is usually always followed by baritan or salvation- presenting a gratitude to God, in the essence of asking salvation for all Gandusari villagers in particular and society in general [32]. Bersih Desa (Cleaning village) with salvation is usually held within a certain time every year; which are often completed with various arts performances for the public entertainment such as wayangan, kleningan and campursari. Various art forms exist in the slopes of Kelud such as Jaranan, Celeng2an and so forth. The diversity is still preserved for generations until now [12]. The form of preservation is manifested in the form of festivals, Kirab budaya (Cultural Kirab) in the month of Suro or carnival that has an impact on the development of tourism potentials in Kemloko, Nglegok and Putukrejo or Gadungan, Gandusari District [33].

The preservation of traditional houses in the form of Javanese house is also done by some members of the community. In the post-eruption they still preserve the form of Joglo Jawa-Timuran in their house renovation. While baritan tradition is not only done at Bersih Desa (the village cleaning) time, but also at family ceremonies such as marriage, pregnancy, birth, circumcision with the aim of asking salvation to God for the whole family. While selamatan performed for various stages of death events as a tribute to relatives who have died and the ancestors. The population is generally Muslim; but faithfully guarding the various forms of tradition without contradicting tradition with the belief in their religion. In the strategy of community development by [34] is called as a cultural or sociocultural strategy, which builds awareness of every individual muslim about the complexity of human environment and develops a rational attitude towards life [35]. This kind of social phenomenon occurs in many places as the life of Islamic societies in Indonesia; as a form of adaptive Islam towards local culture, raising the term of Islam Nusantara. In the treasury of Islamic thought this phenomenon is treated in the concept of Ahlu Sunnah Wal Jamaah which advocates its adherents to merge with the majority, it is not allowed to form exclusive groups resulting in divisions among Muslims [36].

In the village area of Gadungan were found many historical sites, which also reflect how the social life of the community and culture in the past. One of it is Wringin Barnjang temple. When it was first discovered, this temple was wrapped in a banyan tree, therefore the temple was named Wringin Branjang. This temple has a unique architecture and layout. The shape of the temple is quite simple, consisting only of cubic temple-shaped with a pyramid-shaped roofs. The leg of the temple is still buried under the ground. The orientation of this temple is also unique; if most temples facing to the east or the west, this temple just facing to the south. On the slope of
Mount Gedang, Wringin Branjang temple is not alone. Behind it lined up some of the ancient building structures that were getting backwards occupying higher slopes. A sequence from below is Wringin Branjang Temple, then there is the altar for worship in the site Mount Gedang with figures which shows 1231 Saka or 1309 AD as a historical clue of the Site, the time period is included in the era of Majapahit. Various potentials of natural laboratories on the slopes of Kelud, and the ones presented in this paper are just a sample that seems quite prominent in people's lives; there are still many potentials that have not been observed and presented.

This is what the Social Studies students has produced in the context of the Kelud Slopes as the Natural Laboratory for contextual-integrated learning [30]. The development and utilization of well-designed and creative instructional media in Social Studies learning can strengthen students understanding in order to achieve defined competencies. Learning media can also help students improve understanding, facilitate interpretation of data and condense information. The presence of instructional media on the learning process of social studies has a significant meaning because the vagueness of messages or information presented by teachers can be supported by presenting the media of learning. In fact, the Social Studies teachers have little ability to develop or create and use the learning media in teaching-learning process [26] though the material is abstract; in the process of learning, teachers should make it concrete and teach it through the learning media to improve students' understanding.

\section{Reyog Bulkiyo for an Integrated Social Studies Learning}

Reyog Bulkiyo began in Kemloko village since 1897 brought by the soldiers of Diponegoro Prince of Mataram descent named Kasan Muchtar. Laskar (The soldiers) of Diponegoro Prince fled to Kemloko village from the Dutch pursuit after Diponegoro war. Blitar was chosen as a hiding place other than Srengat, because Blitar has fertile soil and dense forest that can be used for farming and hiding by the soldiers. The history of Reyog Bulkiyo has two versions, first tells the war in the island of Java between the army of Prince Diponegoro with the Netherlands. The second version tells King Bulkiyo of Egypt who sought the Prophet Muhammad through war with Karungkolo King.

According to the group leader, Reyog Bulkiyo was created by Kasan Muchtar, he took the story from a book named Ambiyo; which was written in Arabic letters or calligraphy in Javanese language called Pegon. This book tells about the journey of the King of Egypt named King Bulkiyo in search of Prophet Muhammad SAW; but it did not go smoothly because it must go through the battle against Karungkolo King. Currently Reyog Bulkiyo has undergone a third generation; it was inherited to Dhul Majid, Mat Kasri, Djaseman and Ngadi, in one generation later Mat Kasri give it to his son named Khasbulah and Supangi. . Currently the last generation of Reyog Bulkiyo has died and being continued by the new chairman of the Reyog Bulkiyo Dance Circle. He is not a descendant of the last generation because the last generation has only one daughter who is not interested in Reyog Bulkiyo. 


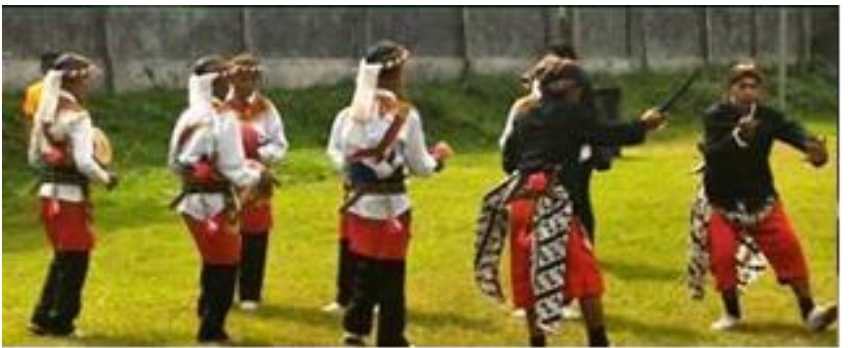

Fig. 1. Reyog Bulkiyo Dance Performance in the Field

The Reyog Bulkiyo dance has a variety of instruments used in performance such as: kecer, terbang thrinting, terbang tiga, terbang gleyohan, terbang gae, kempul jur, kenong and sronen or slompret. There are symbolic meanings of the instruments and the choreography Reyog Bulkiyo Dance performance. The instruments and the koreography of Reyog Bulkiyo are the symbol of the struggle of the Prince Diponegoro soldier in obtaining victory and peace [15]. This is indicated by the clothes worn that use red and white colors. The musical instruments used in Reog Bulkiyo is always the same and cannot be added but still can be reduced if necessary. This happens because Reog Bulkiyo is different from other Reyog dance, where the music used cannot be modified. Reyog Bulkiyo Dance Instruments give meaning that the dance is originally belongs to the people of Java in village of Kemloko. According Adiwikarta [37] in the process of symbolic interactionism of human beings as individuals; make him/her thinks, feels, gives understanding to every circumstance, and gives birth to the reaction and interpretation of every stimulus that he/she attends.

In performing the show, all players/dancer of Reyog Bulkiyo do not use make up but only use a typical outfit consisting of 4 kinds. The typical Reog Bulkio player's outfit. First, one flag-carrier wearing blangkon, long-sleeved white shirt, black-colored beskap, setagen, keris, black trousers, jarit barong and white shoes (additional). Second, two swordsmen wear blangkon clothes, white long-sleeved shirt, black towel, setagen, keris, red pants, jarit barong, black kace and white shoes (additional). Third, six rebana player and warriors wearing blangkon or udeng bawang sebungkul, white longsleeved shirt, black kace, black and red sash, blue setagen, keris, black sampur boro, black trousers, red color skirt and white shoes (additional). Fourth, the player of the musical

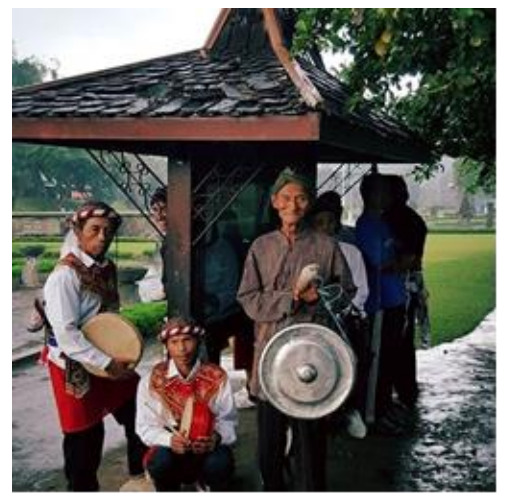

Fig. 2. Dancer Reyog Bulkiyo completed with Instruments

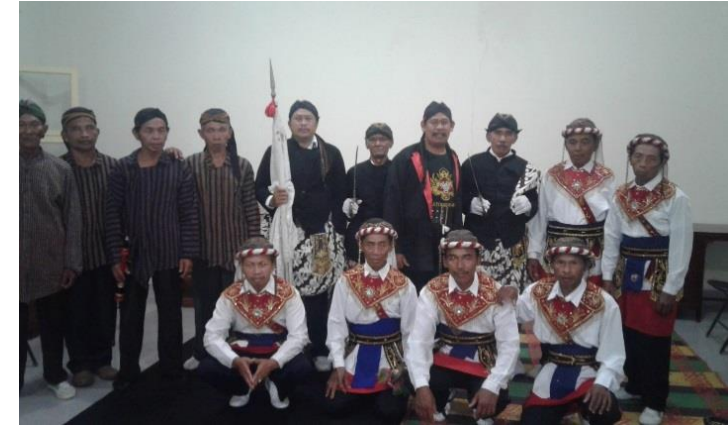

Fig. 3. Reyog Bulkiyo Dancers Team

Instruments wear blangkon, traditional Javanese dress and black trousers [12].

Reyog Bulkiyo is a traditional art that gained influence from Islamic and Hindu culture. This can be seen in the tools used to play Reyog that is a rebana that shows the arts of Islam and gong and kenong that come from the Hindu culture. The many people as actors or player in Reyog Bulkiyo Dance and each person has its own role. First, 5 people carry rebana or tambourine consisting of 1 piece of rebana thrinting, 1 rebana three pieces, 1 rebana gleyoan, and 2 rebana gae. Second, 1 person carrying a pair of kecer or kepyek that serves as the rhythm of the entire instrument Reyog Bulkiyo. Third, 1 person player of trumpet or sronen blower. Fourth, 3 people as $a$ kenong and kempul drummer consisting of kempul (jur) with 2 slendro tone, kenong with 6 slendro tone and bende with 1 slendro tone. Fifth, 1 person as flag carrier, the white color of the flag illustrates that this war is a holy war of the battle between goodness and evil symbolized by Hanoman and Dasamuka images. Sixth, 2 men as swordsman. There is an arguments about the importance of understanding symbols, when researchers use the theory of symbolic interaction theory. Symbols are social objects in the interactions used as representation and communication determined by the people who use them [38]. The people give meaning, create and change objects in the interaction. Such social symbols can take the form of physical objects (visible objects), words (to represent physical objects, feelings, ideas and values), and actions (which people do to give meaning in communicating with others).

Society plays an important role in the preserving a culture, if the society has a desire to participate then, the culture will continue to exist and will not become extinct. Participation is defined as a willingness to help the success of each program according to the ability of everyone without sacrificing their own interests. Kemloko village community participated in the preservation of Reyog Bulkiyo Dance by pioneering dance studio for children. Community participation is indispensable in the process of identifying problems and potentials in the community, selecting and making decisions on alternative solutions to deal with problems, and the process of evaluating the changes [38]. When people participate in preserving the culture will make the culture continues for a long time. In every life of society there will always be problems encountered. In preserving Reyog Bulkiyo is not easy, there are obstacles encountered, one of which is the lack of interest of village youth in Kemloko to learn Reyog Bulkio dance. This 
become a constraint for regeneration of Reyog Bulkio dance to successors. Currently the players of Reog Bulkio are still older generation.

The 2013 curriculum recommends that Social Studies learning be developed in an integrated thematic manner and select from 10 integrated learning models introduced by [39] namely: 1) Connected, 2) Webbed, 3) Integrated, 4) Nested, 5) Fragmented, 6) Sequenced, 7) Slice/Shared, 8) Threaded, 9) Immersed, and 10) Networked [39]. Academically [40] states that of the ten integrated models, the most suitable models applied to the 2013 curriculum are the connected, the webbed model and the integrated model [26], [40]. Anshori's [40] opinion is in line with [24] stating that the policies and recommendations of K2013 are often over-enforced and confuse teachers who are accustomed to instructions; they consider the policy in K2013 is a must. This is where the mismatch between policy and understanding of teachers in the field. What Fogarty [39] writes about integrated learning models is the opinion of academics, in the country of origin there is no obligation to use them. Therefore, when the models become K2013 policies; it is too excited for the condition of Indonesia. It would be wise if the Fogarty [39] model in the K2013 was placed as a recommendation or an appropriate choice in accordance with the conditions of teachers and schools.

The implementation of Natural Laboratory based learning will be a new way of teaching to refresh teacher and student routines in classroom learning. It does not have to be difficult; teachers' skills will evolve along with the use of a The Natural Laboratory for Social Studies. The following are an Integrated Thematic Learning Planning Steps:

- Studying KI/Core competence and KD/Basic Competence of Social Studies subject.

- The determination of themes that fit with the concepts exist in every Social Studies KD.

- Elaboration (formulation) Basic Competence into indicators according to topic/theme.

- The development of integrated thematic syllabus.

- Prepare an integrated thematic Lesson Plan.

- Prepare an integrated thematic materials.

There are two styles of an integrated thematic Social Studies learning. The first style, is learning that tries to combine several subject areas of study/materials in the learning, it becomes a cross-disciplinary teaching [26] such as an integrated model of the spider/Webbed model. The crossfield theme development model difficult for teachers in terms of content mastery of other related fields; as well as in finding friends of teachers to collaborate in learning, school conditions vary widely. The second style is combining different perspectives on a potential theme without the need to seek collaborative partners in the development of integrated thematic Social Studies learning; these opportunities are most likely to be taken by using the potential of a the Natural Laboratory.
The art form of Reyog Bulkiyo, can be designed as learning that allows students to explore various aspects of art such as: how the history of why named Reyog Bulkiyo, what is the story in the arts, who are the characters/actors, what is the meaning behind the story about Reyog Bulkiyo, what is the opinion of the supporting community, how the costumes are worn and what are the meanings, how long is played, with whatever instrument, and in what order is played, how much does it cost in one show, is there any performance fee, how many times people can watch the performance in a month/year, how the impression or perceptions of the audience and so forth. From all these, the preparation of an integrated thematic Lesson Plan requires extra attention from the teacher; Reyog Bulkiyo can be observed from the social-cultural side, the art form, the economic side as a form of creative industry. In the core activities of field-based learning, there should be detailed activities and instruments which explore the perspectives of a Reyog Bulkiyo performance theme. The stages of the activity reflect the effort to explore these detailed perspectives, and those who do so are students from Social Studies Program or students from school by directly watching the Reyog Bulkiyo performance in the community; in this case the teacher and student must know the schedule of Reyog Bulkiyo show.

\section{CONCLUSIONS}

Determining the southern slopes area of Kelud as the Natural Laboratory of the Faculty of Social Sciences and Social Studies Education is a profitable strategic step because the effort of preservation of socio-cultural potentials and various forms of art can be done through education. The Natural Laboratory of the Faculty of Social Sciences is very rich with various potentials can be used for field-based Social Studies learning; from socio-economic, socio-cultural, artistic and historical potentials. The potentials of socio-cultural are very much reflects the ethnic and cultural diversity in the community on the slopes of Kelud such as: cleaning the village/bersih desa events are usually followed by baritan or salvation; completed with various art form as the entertainment for the community such as wayangan, kleningan and campursari, Jaranan, Celeng-celengan and Reyogan and so forth. To preserve the socio-cultural potential of various forms of art is embodied in the form of festivals, cultural carnival in the month of Suro. The carnival has an impact on the development of tourism potential in Kemloko and Gandusari District. Society play an important role in the preserving a culture; society has a desire to participate then the culture will continue to exist and will not extinct. Reyog Bulkiyo is one form of art on the southern slope of Kelud that can be raised as the theme of social Studies theme/material about the diversity of society and culture. With interdisciplinary integrated Social Studies learning styles require interdisciplinary knowledge from teachers/teacher-seeking opportunities for from different disciplines to collaborate in developing integrated Social Studies as environment-based learning. Reyog Bulkiyo can be discussed with the students from various perspectives. Hopefully, this IDB-sponsored research can be continued to examine many hidden potentials of the Natural Laboratory and mentoring teachers in using The Natural Laboratory to to improve their skills in practicing an integrated Social Studies learning based on the natural environment. 


\section{REFERENCE}

[1] F. Fatkhuroyan and W. Trinah, "Volcanic Ash Monitoring using Himawari-8 and OMI (Ozone Mapping Instrument) Remote Sensing Satellites," Maj. Ilm. Globe, vol. 19, no. 1, pp. 33-44, 2017.

[2] P. I. Wardhani, E. D. Lestari, and G. M. . Wardhana, "Analysis of Public and Government Preparedness in Facing Eruption of Gunungapi Kelud Year 2014," in Potpourri of Research: Disaster Management in Kelud during the Eruption Crisis Period 2014, J. Sartohadi and E. S. Pratiwi, Eds. Yogyakarta: Student Literature, 2014, pp. 125-143.

[3] É. De Bélizal, F. Lavigne, J. C. Gaillard, D. Grancher, I. Pratomo, and J. C. Komorowski, "The 2007 eruption of Kelut volcano (East Java, Indonesia): phenomenology, crisis management and social response," Geomorphology, vol. 136, no. 1, pp. 165-175, 2012.

[4] R. A. Atok, Purwanto, and D. Taryana, "Spatial Characteristics of Physical, Social, Cultural Potential of Southern Slope of Kelud Mountain," Malang, 2015.

[5] "Kelud Mountain. Geological Agency of the ESDM Ministry," $P V M B G$ (Volcanology and Volcanic DisasterCenter), 2013. [Online]. Available: http://www.vsi.esdm.go.id/index.php/gunungapi/data-dasargunungapi/538-g-kelud. [Accessed: 08-Feb-2017].

[6] B. Retnoaji, F. Nanda, D. Sartika, N. Eunike, D. D. Oktaviani, and D. Afriani, "The effect of volcanic dust on the histological structure of wader pari (Rasbora lateristriata Bleeker, 1854) organs," AIP Publ., vol. 1744, no. 1, p. 020007-, 2016.

[7] N. A. Sprintall and R. C. Sprinthall, Educational Psychology. Mc Graw Hill Book Co, 1990.

[8] Desmita, Psychology Development of Learners. Bandung: Remaja Rosdakarya, 2011.

[9] S. Sapriya, Pendidikan IPS. Bandung: Remaja Rosdakarya, 2015.

[10] M. Masrukhi, "Revitalization of Citizenship Education Learning as Character Building through School Culture Empowerment," J. Educ. Sci., vol. 17, no. 1, pp. 15-21, 2010.

[11] M. Davidson, "A Character Education Research Perspective for The 21st Century," J. Character Educ., vol. 10, no. 1, pp. 77-83, 2014.

[12] A. Alfath, E. Dahmian, and P. Yogi, Setya, "The Festival of 1000 Tumpeng: Commodification of Tradition, Tourism and territoriality in Kelud Mountain," J. Masy. Kebud. dan Polit., vol. 29, no. 4, pp. 169180, 2016.

[13] D. Meirawan, "The Human Character Trilogy is Dignified and Its Implications on Education," J. Educ. Sci., vol. 17, no. 3, pp. 189-194, 2010.

[14] I. N. Ruja, "Survey Permasalahan Implementasi Kurikulum Nasional 2013 Mata Pelajaran Ilmu Pengetahuan Sosial Sekolah Menengah Pertama di Jawa Timur," J. Sej. dan Budaya, vol. 9, no. 2, pp. 193-199, 2015.

[15] A. Muntadhirotul, "Tinjauan Koreografi Reyog Bulkiyo di Desa Kemloko Kacamatan Nglegok Kabupaten Blitar," Institut Seni Indonesia Surakarta, 2014.

[16] I. Santoso, "Pasukan Khusus Pangeran Diponegoro Masih Menari (Study Historis Kesenian Tari Tradisional Reyog Bulkiyo Blitar)," J. Sosiol. Pendidik. Humanis, vol. 1, no. 1, pp. 21-27, 2016.

[17] I. Indranata, A Qualitative Approach to Quality Control. Jakarta: UIPress, 2008.

[18] C. John W, Qualitative Approach, Quantitative, and Mixed.Third Edition, Fourth Edi. SAGE Publications, Inc., 2014.

[19] S. Arikunto, "Research procedures a practice approach," 2006.

[20] M. B. Miles and A. M. Huberman, Qualitative Data Analysis: The Source Book of New Methods. Jakarta: UI-Press, 1992.

[21] S. Sugiyono, Understanding Qualitative Research. Bandung: Alfabeta, 2013.

[22] N. Denzin and L. Y., Handbook of Qualitative Research. 1994.

[23] J. Jarolimek, Social Studies in Elementary Education. New York: Mc Millan Company, 1990.

[24] S. M. Towaf, "Character Education in IPS Subject," J. Educ. Sci., vol. 20 , no. 1 , pp. $75-85,2014$.
[25] [B. Maftuh, "Strengthening the role of IPS in social skills," 2010. [Online]. Available: http://file.upi.edu/Direktori/PIDATO/3._PIDATO_PENGUKUHAN_B UNYAMIN.pdf. [Accessed: 01-Aug-2017].

[26] D. Daryanto, Integrated Thematic Learning (Curriculum 2013). Yogyakarta: Media Style, 2014.

[27] I. K. Ahmadi and S. Amri., Mengembangkan pembelajaran IPS terpadu. jakarta: Prestasi Pustaka, 2011.

[28] Fadillah, Implementation of Curriculum 2013 in Learning SD/MI, SMP/MTs, and SMA /MA. Yogyakarta: Ar-Ruzz Media, 2014.

[29] Kemendikbud, Peraturan Pemerintah No 41 Tahun 2007: Standar Proses untuk Satuan Pendidikan dan Menengah. Indonesia: BSNP, 2007.

[30] T. Trianto, Designing Innovative-Progressive Learning. Jakarta: Kencana Prenada Media, 2010.

[31] C. Parker, Walter, Social Studies in Elementary Education, 13th Editi. Boston: Pearson, Allyin Bacon, 2009.

[32] A. Watson, "No TitleSelf-deception and survival: Mental coping strategies on the Western Front, 1914-18.," J. Contemp. Hist., vol. 41, no. 2, pp. 247-268, 2006.

[33] R. Destawan, A. Bernando, M. Aziz, and I. R. Palupi, "Application of tomography seismic for subsurface modeling of Kelud Mountain.," AIP Conf. Proc., vol. 1730, no. 1, p. 50008, 2016.

[34] A. Wahid, Moving the Tradition. Yogyakarta: LKIS, 2010.

[35] F. Willems, E. Denessen, C. Hermans, and P. Vermeer, "Assessing qualities of moral classroom conversations in the domain of citizenship education: A virtue ethical approach," J. Res. Character Educ., vol. 9, no. 2, pp. 107-119, 2013.

[36] M. A. Fattah, Tradition of NU people. Yogyakarta: Pustaka Pesantren, 2008.

[37] D. Erawati, "Analisis Interaksionisme Simbolik (Makna Terhadap Peserta Didik Dalam Pendidikan)," Pedago. J. Pendidik., vol. 8, no. 2, pp. 45-53, 2013.

[38] I. R. Adi, Perencanaan partisipatoris berbasis aset komunitas : dari pemikiran menuju penerapan. Depok: FISIP UI Press, 2007, 2007.

[39] R. Fogarty, "How to Integrate the curricula," IRI/Skylight Publishing, Palatine, IL, 1991.

[40] S. Anshori, "Thematic-Integrative Learning of IPS Subjects in Curriculum 2013," Sci. J. PGSD, vol. 42, no. 2, pp. 42-53, 2014. 